\title{
IODP Expedition 331: Strong and Expansive Subseafloor Hydrothermal Activities in the Okinawa Trough
}

\author{
by Ken Takai, Michael J. Mottl, Simon H.H. Nielsen and \\ the IODP Expedition 331 Scientists
}

\begin{abstract}
Integrated Ocean Drilling Program (IODP) Expedition 331 drilled into the Iheya North hydrothermal system in the middle Okinawa Trough in order to investigate active subseafloor microbial ecosystems and their physical and chemical settings. We drilled five sites during Expedition 331 using special guide bases at three holes for reentry, casing, and capping, including installation of a steel mesh platform with valve controls for postcruise sampling of fluids. At Site C0016, drilling at the base of the North Big Chimney (NBC) mound yielded low recovery, but core included the first Kuroko-type black ore ever recovered from the modern subseafloor. The other four sites yielded interbedded hemipelagic and strongly pumiceous volcaniclastic sediment, along with volcanogenic breccias that are variably hydrothermally altered and mineralized. At most sites, analyses of interstitial water and headspace gas yielded complex patterns with depth and lateral distance of only a few meters. Documented
\end{abstract}

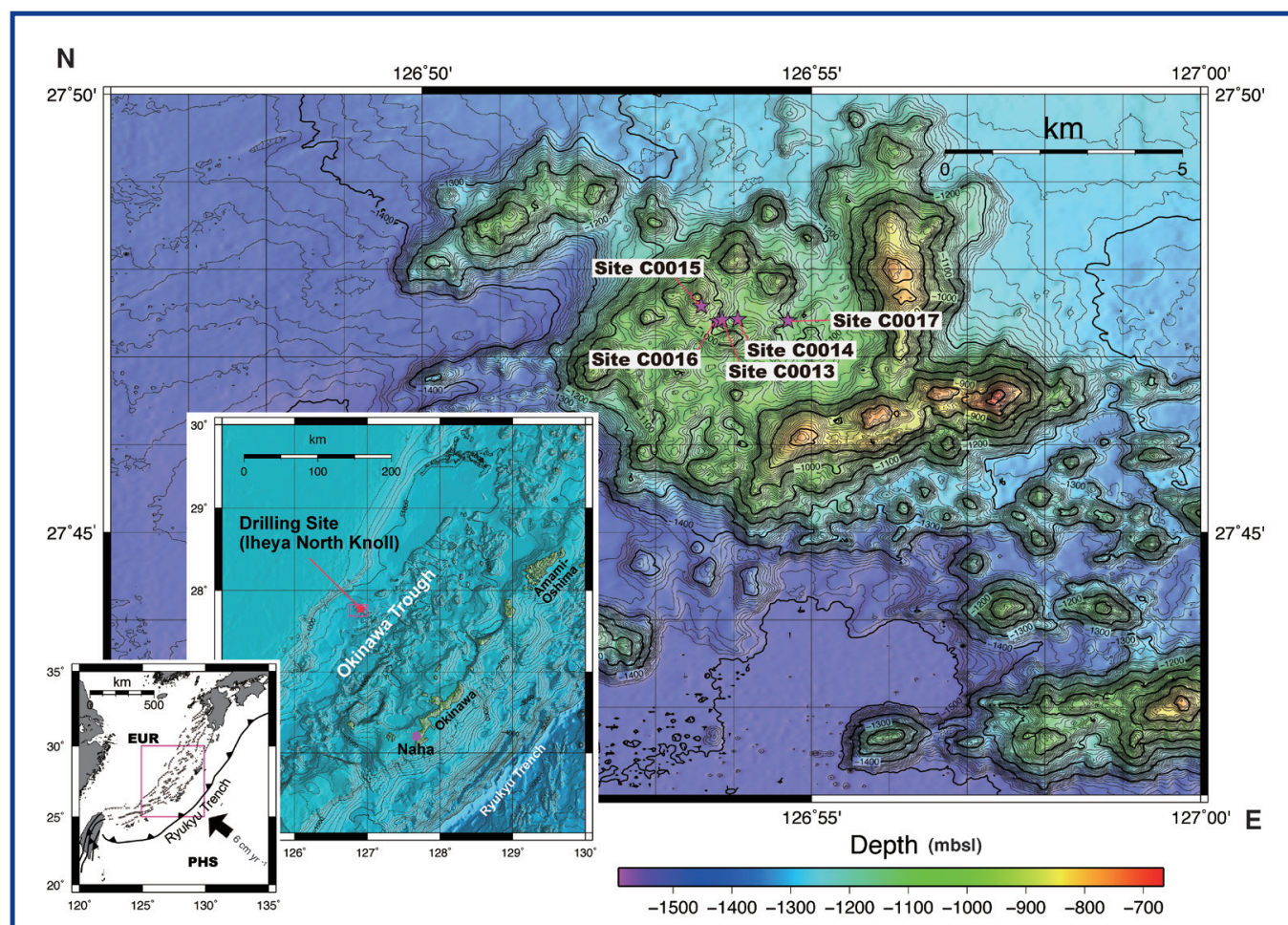

Figure 1. Area map of Iheya North Knoll showing Sites C0013-C0017 drilled during Expedition 331. Insets show the Iheya North Knoll in relation to Okinawa and Okinawa in relation to major tectonic components. EUR= Eurasian Plate, PHS = Philippine Sea Plate. Modified from Takai et al. (2011). processes included formation of brines and vapor-rich fluids by phase separation and segregation, uptake of $\mathrm{Mg}$ and $\mathrm{Na}$ by alteration minerals in exchange for $\mathrm{Ca}$, leaching of $\mathrm{K}$ at high temperature and uptake at low temperature, anhydrite precipitation, potential microbial oxidation of organic matter and anaerobic oxidation of methane utilizing sulfate, and methanogenesis. Shipboard analyses have found evidence for microbial activity in sediments within the upper 10-30 m below seafloor (mbsf) where temperatures were relatively low, but little evidence in the deeper hydrothermally altered zones and hydrothermal fluid regime.

\section{Introduction and Goals}

Active seafloor hydrothermal systems at mid-ocean ridges, volcanic arcs, backarc basins, and hotspots are environments with extraordinarily high fluxes of energy and matter. The "subvent biosphere" is the subseafloor biosphere that is predicted to exist just beneath active hydrothermal vents and fluid discharge zones and is sustained from the hydrothermal energy and matter inputs (Deming and Baross, 1993; Takai et al., 2001). The existence of a subvent biosphere has been inferred from many microbiological and geochemical investigations of vent chimney structures and diffuse hydrothermal fluids (Nunoura and Takai, 2009; Nunoura et al., 2010; Takai et al., 2008; 2009; and references in Takai et al., 2006, and Huber and Holden, 2008). In the Iheya North field, a typical deep-sea hydrothermal system in the Okinawa Trough, it has been suggested that a variety of microbial communities based on different chemolithoautotrophic primary producers is present in subseafloor habitats (Nakagawa et al., 
2005). Variability in potential subseafloor microbial communities is likely associated with physical and chemical variation of hydrothermal fluids, controlled by phase-separation and phase-partition of hydrothermal fluid beneath the seafloor. In addition, the overall hydrothermal environments associated with organic-rich sediments provide unusual amounts of $\mathrm{C} 1$ compounds $\left(\mathrm{CO}_{2}\right.$ and $\left.\mathrm{CH}_{4}\right)$ in hydrothermal fluids as carbon sources, as well as unique microbial habitats affected by liquid $\mathrm{CO}_{2}$ and gas hydrates (Nakagawa et al., 2005; Kawagucci et al., 2011). Thus, the abundant supply of energy and carbon and the richness of the habitats supported by physical and chemical variations in the Iheya North field provide an ideal setting for the formation of functionally and metabolically diverse subseafloor microbial communities associated with hydrothermal activity.

There were three major scientific objectives of Expedition 331 drilling were.

1. to test for the existence of a functionally active, metabolically diverse subvent biosphere associated with subseafloor hydrothermal activity;

2. to clarify the architecture, function, and impact of subseafloor microbial eco-systems and their relationship to physical, geochemical, and hydrogeologic variations within the hydrothermal mixing zones around the discharge area; and

3. to establish artificial hydrothermal vents in cased holes from potential subseafloor hydrothermal flows, and to prepare a research platform at each cased hole for later study of fluids tapped from various parts of the hydrothermal system and their associated microbial and macrofaunal communities.

\section{Geological Setting and Earlier Work}

The Okinawa Trough is a backarc basin extending for $\sim 1200 \mathrm{~km}$, between the Ryukyu arc-trench system and the Asian continent (Fig. 1; Lee et al., 1980; Letouzey and

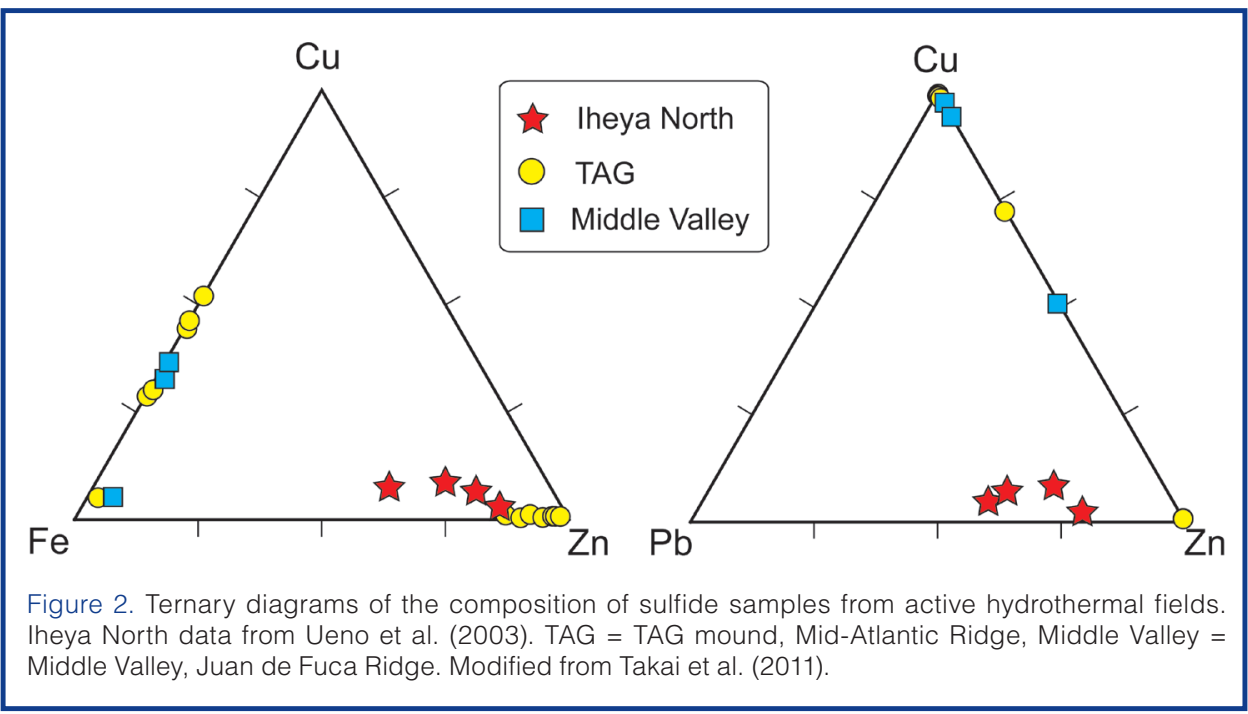

Kimura, 1986). Seismic reflection data suggest a typical backarc structure (Letouzey and Kimura, 1986) with a high-velocity mantle below $\sim 6000$ mbsf overlain by potentially young basalt with an average velocity of $5.8 \mathrm{~km} \mathrm{~s}^{-1}$ between $\sim 3000 \mathrm{mbsf}$ and $6000 \mathrm{mbsf}$, an igneous rock layer $\left(4.9 \mathrm{~km} \mathrm{~s}^{-1}\right)$ between $1000 \mathrm{mbsf}$ and $3000 \mathrm{mbsf}$, and $\sim 1000 \mathrm{~m}$ of sediment immediately beneath the seafloor. Since the discovery of submarine hydrothermal activity at Iheya Ridge and Izena Hole in the middle Okinawa Trough in 1988 (Halbach et al., 1989; Sakai et al., 1990), six active hydrothermal fields have been discovered-Minani-Ensei Knoll, Iheya North, Iheya Ridge, Izena Hole, Hatoma Knoll, and Yonaguni Knoll IV.

Characteristics of the tectonic setting in this active hydrothermal system are reflected in the chemical composition of sulfide deposits. Sulfide samples collected from the Iheya North field are distinctly more enriched with $\mathrm{Pb}$ than mid-oceanic-ridge sulfides (Fig. 2). The polymetallic $\mathrm{Zn}-\mathrm{Pb}-\mathrm{Cu}$ chemical signature of Iheya North sulfides is similar to that of Kuroko-type hydrothermal deposits formed during the Tertiary in northeast Japan.

The chemistry of hydrothermal fluids collected from active sulfide chimneys in the Okinawa Trough is characterized by higher concentrations of $\mathrm{CO}_{2}, \mathrm{CH}_{4}, \mathrm{NH}_{4}$, I, and $\mathrm{K}$ and higher alkalinity than those in typical sediment-free midocean-ridge hydrothermal fluids (Sakai et al., 1990; Gamo et al., 1991; Konno et al., 2006; Takai and Nakamura, 2010; Kawagucci et al., 2011). The distinctive hydrothermal fluid chemistry is strongly linked with the geologic setting and the thick terrigenous sediments of the Okinawa Trough. Philippine Plate subduction along the Ryukyu arc-trench system supplies dacitic-rhyolitic magma rich in $\mathrm{K}$ and volatile components to the Okinawa Trough (Sakai et al., 1990; Gamo et al., 2006). Organic-rich terrigenous sediment filling the Okinawa Trough (Narita et al., 1990) supplies not only the sedimentary chemical inputs $\left(\mathrm{NH}_{4}\right.$, I, etc.; Gamo et al., 1991; You et al., 1994), but also promotes the widespread occurrence of functionally active microbial communities that impact hydrothermal fluid chemistry and circulation (Nakagawa et al., 2005; Inagaki et al., 2006; Nunoura and Takai, 2009; Nunoura et al., 2010; Takai and Nakamura, 2010; Kawagucci et al., 2011). In addition to the chemical aspects, the relatively shallow water depth of many Okinawa Trough hydrothermal systems serves to induce subcritical phase separation (Suzuki et al., 2008) and subsequent phase segregation, as the boiling temperature of seawater decreases steeply with decreasing pressure at 100 bar. Phase separation and segregation sometimes 


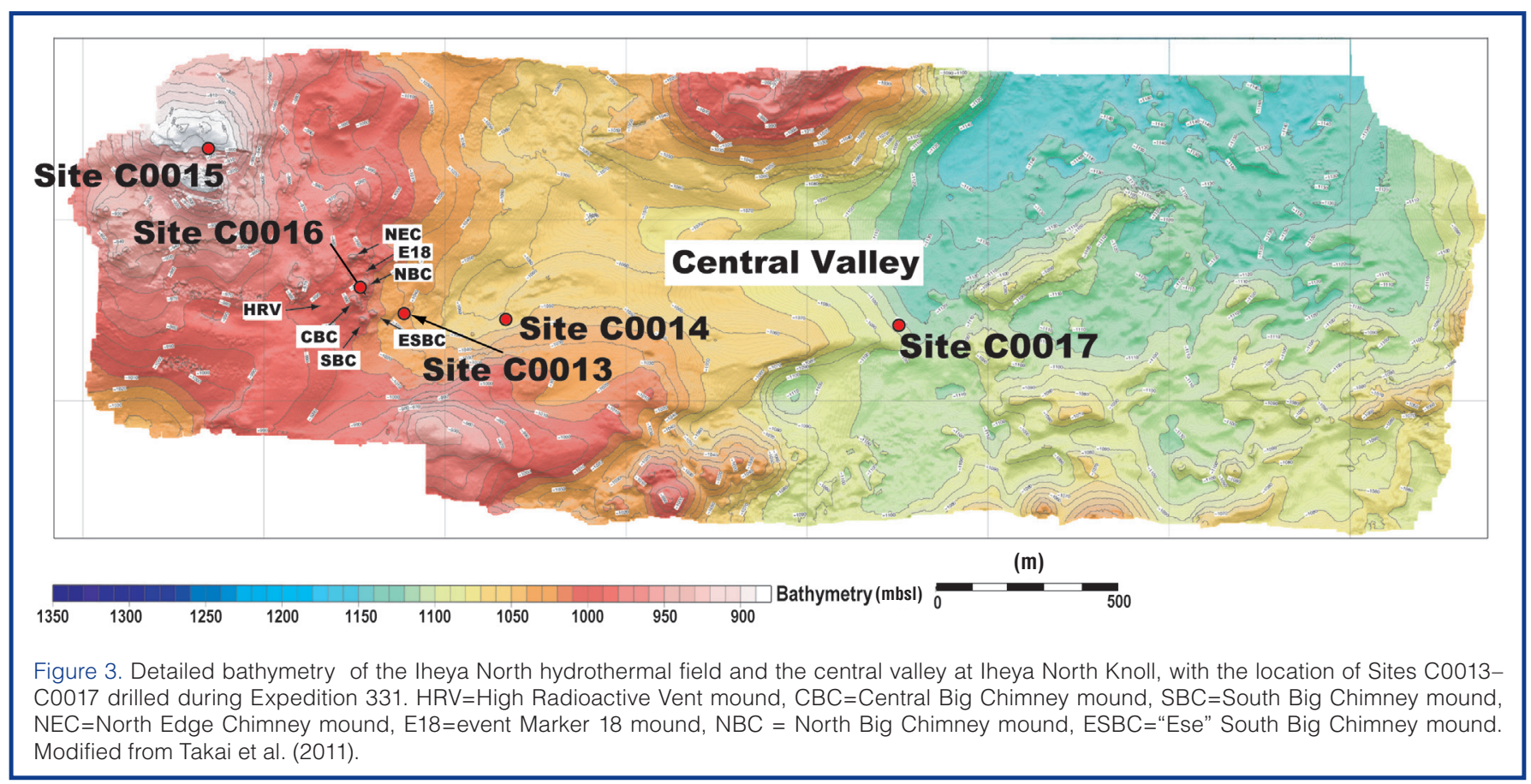

produce hydrothermal fluids of quite different chemical composition at different vent sites in the same hydrothermal field, even though they are derived from the same source fluid (Kawagucci et al., 2011).

\section{Drilling, Temperature Measurement, Sampling, and Installation of Vents}

We drilled five sites during Expedition 331: the active hydrothermal vent site and sulfide-sulfate mound at North Big Chimney (NBC) (Site C0016, Fig. 3), three sites east of NBC at distances of $\sim 100 \mathrm{~m}$ (C0013), $450 \mathrm{~m}$ (C0014), and $1550 \mathrm{~m}$ (C0017) from the active vents, and one site (C0015) on a hill $\sim 60 \mathrm{~m}$ northwest of the active vents that represents a potential migration path for hydrothermal fluid.

The NBC hydrothermal mound at Site C0016 is $20 \mathrm{~m}$ high and $6 \mathrm{~m}$ in diameter. When we attempted to core this active high-temperature $\left(311^{\circ} \mathrm{C}\right)$ vent at its summit, the pipe broke, and core recovery failed (Hole C0016A). We drilled a second hole $20 \mathrm{~m}$ away, immediately at the base of the mound on its western side (Hole C0016B). We used conventional hard rock drilling equipment supplied by Baker-Hughes Inteq (BHI) specifically for Expedition 331 due to high temperatures and expectation of hard rock. The BHI system collects 4-inch diameter core in aluminum liners in lengths of $9 \mathrm{~m}$, $18 \mathrm{~m}$, or $27 \mathrm{~m}$, but requires a time-consuming pipe trip for each core. It penetrated to $45 \mathrm{mbsf}$ in three runs of $9 \mathrm{~m}, 18 \mathrm{~m}$, and $18 \mathrm{~m}$. Each run recovered several large pieces of core, but the total recovery was only 2.095 meters, nearly all of it hard rock. The only evidence for the actual depths of the recovered rock thus comes from the drilling records. Hole C0016B was not cased, but it was fitted with a corrosion cap with $3 \mathrm{~m}$ of 5.5 -inch pipe hanging beneath and extending $0.4 \mathrm{~m}$ into the seafloor (Fig. 4). ROV video images showed vigorous black smoker discharge from the corrosion cap outlet immediately after its deployment. This hydrothermal emission began only after the third coring run, which penetrated $27-45 \mathrm{mbsf}$, and was probably derived from a depth below 38 mbsf.

At Sites C0013, C0014, and C0017, we drilled the relatively high, moderate, and low heat flow areas, respectively, to the east of the Iheya North hydrothermal field to investigate subseafloor microbial habitats and communities within broad gradients of physical and chemical variation, both laterally and vertically, that could be affected by mixing between discharging hydrothermal solutions and recharging ambient bottom seawater. These sites were drilled using the hydraulic piston coring system (HPCS) to first refusal and then again in any softer intervals encountered deeper in the hole, alternating as necessary with the extended punch (EPCS) and extended shoe (ESCS) coring systems, and, for one run at Site C0013, the BHI system, to penetrate the harder layers. Both the EPCS and ESCS systems were able to penetrate the harder layers, with a slight advantage to the ESCS for the hardest layers, though the EPCS was generally much better at core recovery. We penetrated the margin of the local discharge-recharge zone to depths of $55 \mathrm{mbsf}$ (C0013), $137 \mathrm{mbsf}$ (C0014), and $151 \mathrm{mbsf}$ (C0017), coring variably hydrothermally altered sediment and pumiceous deposits (Figs. 5, 6). We were able to measure in situ temperature at two of these sites using the advanced piston corer temperature tool (APCT3) shoe (upper calibration limit $=55^{\circ} \mathrm{C}$ ) as part of the HPCS, combined with commercial thermoseal strips (Nichiyu Giken Co., Ltd.) taped to the outer surface of the core liner. We were not able to measure temperature at proximal flank Site C0013, but the gradient was likely higher than at the other two flank sites. 
Eight holes (C0013A-C0013H) were drilled at Site C0013, and core was recovered from all but Hole C0013A. Hole C0013E was the deepest ( $54.5 \mathrm{mbsf}$ ) and was cased down to 40.2 mbsf and fixed with a corrosion cap (open outlet pipe) mounted on the guide base (Fig. 4). During drilling and coring operations at Site C0013, we encountered many operational and sample handling problems. These problems were due to the unexpectedly high temperature gradient at the site and the presence of repeated hard layers that appear to behave as cap rocks alternating with soft and sticky clay-rich layers. Porosity measurements on the core clearly document the repeated occurrence of low-porosity harder layers (e.g., 0-2 mbsf, 7-10 mbsf, and 20-30 mbsf). We observed at several depths that when a hard cap rock was drilled through into softer underlying layers, subseafloor hydrothermal fluid began to outflow from the hole, where it was imaged by the ROV video camera. To tap this fluid, we used slotted, perforated casing pipe over the depth interval 21-39.8 mbsf in Hole C0013E (Fig. 4). Immediately after casing and capping this hole, we observed in the ROV video image strong hydrothermal fluid discharge from the casing pipe that was hung in the guide base. Thermoseal temperature-sensitive strips on the corrosion cap outlet pipe showed in the ROV video imagery that the discharging water temperature was $>250^{\circ} \mathrm{C}$.

Seven holes were drilled at Site C0014 (Holes C0014AC0014G). Hole C0014G was the deepest (136.7 mbsf) and was cased down to $117.8 \mathrm{mbsf}$ and fixed with a corrosion cap (open outlet pipe) mounted on the guide base. As at Site C0013, we encountered repeated hard layers that behaved as cap rock, and discharge from the holes, beyond what may be only expelled drilling fluid, after penetrating these layers (35-44.5 mbsf in Hole C0014B, 25.5-35 mbsf in Hole C0014E, and 37.7-47.2 mbsf and 89.2-93.7 mbsf in Hole C0014G). We again cored multiple low-porosity layers (e.g., in Holes C0014B, C0014E, and C0014G). Based on pore water chem- istry, density, and porosity (and indicated by low recovery during drilling), we inferred lateral hydrothermal flow at 31-42.5 mbsf and 90-95 mbsf at Site C0014. We therefore installed slotted, perforated casing pipe at 29.8-49.2 mbsf, 78.3-97.8 mbsf, and 107.5-117.2 mbsf in Hole C0014G (Fig. 4).After casing and capping, we saw in the ROV-mounted video diffuse hydrothermal fluid discharge, not from the corrosion cap outlet but from the seafloor, through the annulus, the space between the wall of the hole and the casing pipe. The temperature of the diffusing fluids was found to be $>240^{\circ} \mathrm{C}$ based on exposure of thermoseal strips mounted on the corrosion cap outlet pipe. We measured temperature at Site C0014 using the APCT3 temperature shoe on the HPCS core barrel for lower temperatures $\left(0^{\circ} \mathrm{C}-55^{\circ} \mathrm{C}\right)$ and thermoseal temperature-sensitive strips for higher temperatures $\left(75^{\circ} \mathrm{C}-250^{\circ} \mathrm{C}\right)$. The temperature-depth profile at Site $\mathrm{C} 0014$ is shown in Fig. 7a. Temperature increases nearly linearly at $3^{\circ} \mathrm{C} \mathrm{m}^{-1}$ to $145^{\circ} \mathrm{C} \pm 5^{\circ} \mathrm{C}$ at $47 \mathrm{mbsf}$ and then increases abruptly to $>210^{\circ} \mathrm{C}$ at $50 \mathrm{mbsf}$, below a hard layer near that depth. The drilled sequence at Site C0014 comprises interbedded, variably altered, and consolidated volcaniclastic gravels and breccias, as well as hemipelagic mud (Fig. 5). Given the location of the site on the upper flank of an active volcanic complex, mass wasting and debris flows are likely to be important sedimentary processes, potentially leading to high rates of redeposition of hemipelagic and volcaniclastic material. The deeper portion of the rock volume cored has been hydrothermally altered. Differing degrees and styles of hydrothermal alteration form the basis for the division of Site C0014 sediments and lithologies into lithostratigraphic units.

Hole C0017D is the deepest (150.7 mbsf) of four holes drilled at Site C0017 and is located 1550 m east of the hightemperature vents. Based on its low heat flow, it was inferred to be a location of probable recharge of the hydrothermal system. We observed no evidence for discharge of water from any of these holes, but the concave-upward tempera-

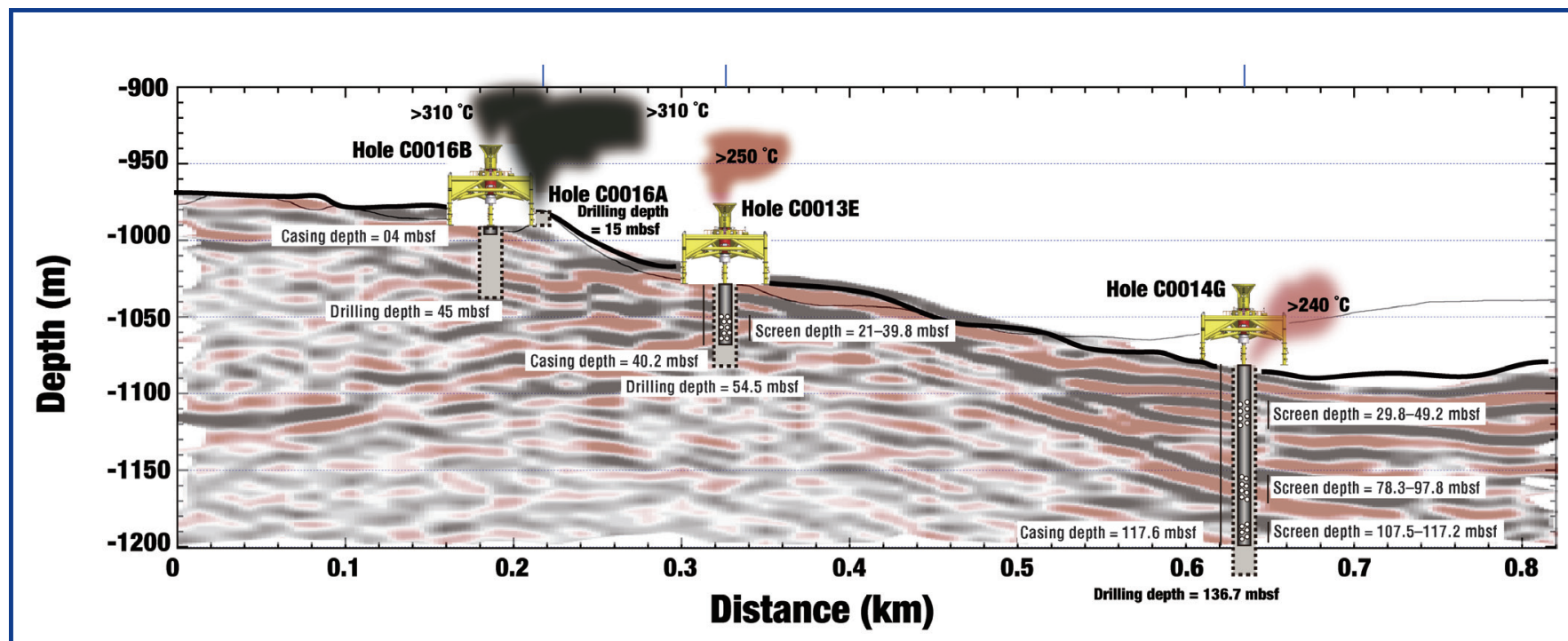

Figure 4. Schematic illustration of post-drilling natural and artificial hydrothermal vents created during Expedition 331. Outflow temperatures measured by ROV (Hole C0013E) and thermal stickers (Holes C0014G and C0016B). Modified from Takai et al. (2011). 
ture profile we measured (Fig. 7b) can be fit reasonably well with an exponential function and is consistent with overall downwelling, with distinct perturbations in the temperature gradient that suggest localized lateral flow that may be influenced by the variable lithologies we cored (Fig. 6). We measured temperature successfully at seven depths in Holes C0017B-C0017D over the interval 18.3-150.7 mbsf; combined with the ocean bottom water temperature at the site of $4.9^{\circ} \mathrm{C} \pm 0.5^{\circ} \mathrm{C}$, our profile is defined by eight points. Six of the downhole measurements were made using the APCT3 tempera-

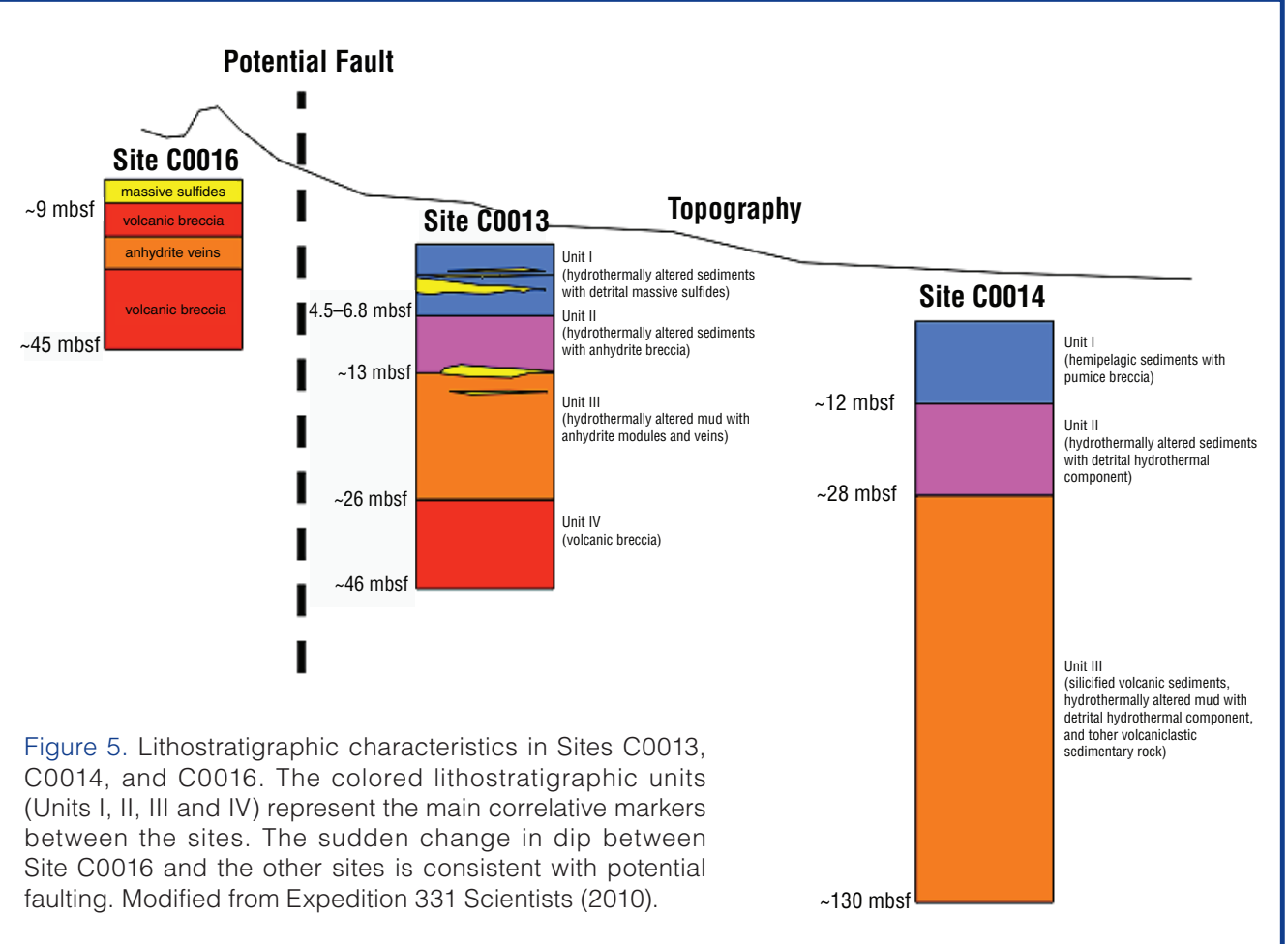
ture shoe on the HPCS. The seventh and deepest measurement, at $150.7 \mathrm{mbsf}$, was made in triplicate using three identical thermoseal temperature-sensitive strips with chemically impregnated beads for $75^{\circ} \mathrm{C}, 80^{\circ} \mathrm{C}, 85^{\circ} \mathrm{C}, 90^{\circ} \mathrm{C}$, and $95^{\circ} \mathrm{C}$ taped to the bottom outer surface of the plastic core liner. These beads were darkened and thus exposed at maximum temperatures of $85^{\circ} \mathrm{C}, 90^{\circ} \mathrm{C}$, and $90^{\circ} \mathrm{C}$ on the three strips, which we reported as $90^{\circ} \mathrm{C} \pm 5^{\circ} \mathrm{C}$. The APCT3 shoe recorded a temperature in excess of its maximum range of $55^{\circ} \mathrm{C}$ for this core. Down to $\sim 50 \mathrm{mbsf}$, where we encountered a hard layer that was probably pumice (no core was recovered, Fig. 6), temperature remained low, $<15^{\circ} \mathrm{C}$. Beneath this hard layer, temperature jumped to $25^{\circ} \mathrm{C}-39^{\circ} \mathrm{C}$ at $69-85 \mathrm{mbsf}$ and then appeared to level off for a short interval, reaching only $44^{\circ} \mathrm{C}$ at $112 \mathrm{mbsf}$ before increasing nearly exponentially to $90^{\circ} \mathrm{C}$ at the bottom of Hole C0017D at $150.7 \mathrm{mbsf}$.

Three holes were drilled at Site C0015 (Holes C0015A$\mathrm{C} 0015 \mathrm{C})$. Although a relatively short interval was cored (0-9.5 mbsf), a broad diversity of sediment types was drilled, with coarse pumiceous gravel and grit, siliciclastic sand, hemipelagic mud, bioclastic gravel, and foraminiferal sediment all recovered. In contrast to the other sites, the samples of Site C0015 do not have any significant hydrothermal input, nor do they appear at present to support a robust microbial community associated with hydrothermal activity. Thus, Site C0015 is excluded from further description and discussion.

\section{Preliminary Scientific Results}

Drilling and coring operations during Expedition 331 provided insight into the hydrothermal flow regime at Iheya North Knoll. While the thermal gradient was known to be

high at Site C0016 at NBC mound, Sites C0013 and C0014 have steeper thermal gradients than we expected. Site C0013 was located $100 \mathrm{~m}$ east of the vigorous high-temperature vents and mounds (Fig. 3). Drilling to our maximum depth of $54.5 \mathrm{mbsf}$, we penetrated several hard, low-porosity layers that could function as a cap rock and found thick, porous sediment hydrothermally altered at high temperature between the harder, less permeable layers. The interstitial water showed large changes in composition both laterally and vertically over short distances, suggesting chaotic lateral flow in permeable horizons separated by impermeable barriers. The lithostratigraphy, physical properties of the sediment and rock, and interstitial water chemistry thus all provided insight into the hydrothermal flow regime at Site C0013.

Site C0014 was located $\sim 50$ m east of the high-temperature vents and mounds (Fig. 3). The temperature gradient was roughly linear from 0 mbsf to $47 \mathrm{mbsf}$, increasing from the bottom water temperature of $4.5^{\circ} \mathrm{C}$ to $145^{\circ} \mathrm{C}$ over that depth range, but it deviated greatly from this line at $0-9 \mathrm{mbsf}$ and 47-50 mbsf, where it was clearly affected by high-temperature fluid pooling or lateral flow. Interstitial water chemistry demonstrated vertical stratification, from water with seawater chloride values at $0-25 \mathrm{mbsf}$, to a vapor at $29-38 \mathrm{mbsf}$, and to a brine from $48 \mathrm{mbsf}$ to the deepest sample at $114 \mathrm{mbsf}$. Within the upper sediments, which consisted of pelagic sediments and pumiceous gravel, there was considerable lateral variability in the intensity of microbial sulfate reduction between the four holes that were only a few meters apart; clearly there was a functionally robust and metabolically diverse subseafloor biosphere here. At $20 \mathrm{mbsf}$, where the temperature was $\sim 70^{\circ} \mathrm{C}$, and to the bottom of the deepest Hole C0014G at 137 mbsf, where a linear fit would have the 
temperature exceed $400^{\circ} \mathrm{C}$, the sediment and rock we recovered was intensely hydrothermally altered. As at Site C0013, chaotic flow should be occurring through permeable formations and along fault structures, and was likely separated vertically by impermeable beds that behave as cap rocks.

Site C0017 was located 1550 m east of the high-temperature vents of the Iheya North hydrothermal field, in an area of low heat flow (Fig. 3). The overall temperature profile was exponential and concave upward, consistent with downwelling of cold water, implying that this was an area of recharge to the hydrothermal system. We reached a maximum temperature of $90^{\circ} \mathrm{C} \pm 5^{\circ} \mathrm{C}$ at the bottom of the deepest Hole C0017D at $151 \mathrm{mbsf}$. Deviations from a smooth temperature profile indicated the presence of a discrete zone of cold water recharge, consistent with interstitial water chemistry and the presence of a highly oxidized layer at 26-35 mbsf that supported a microbial community. We found only a small amount of hydrothermally-altered sediment deep in Hole C0017D.

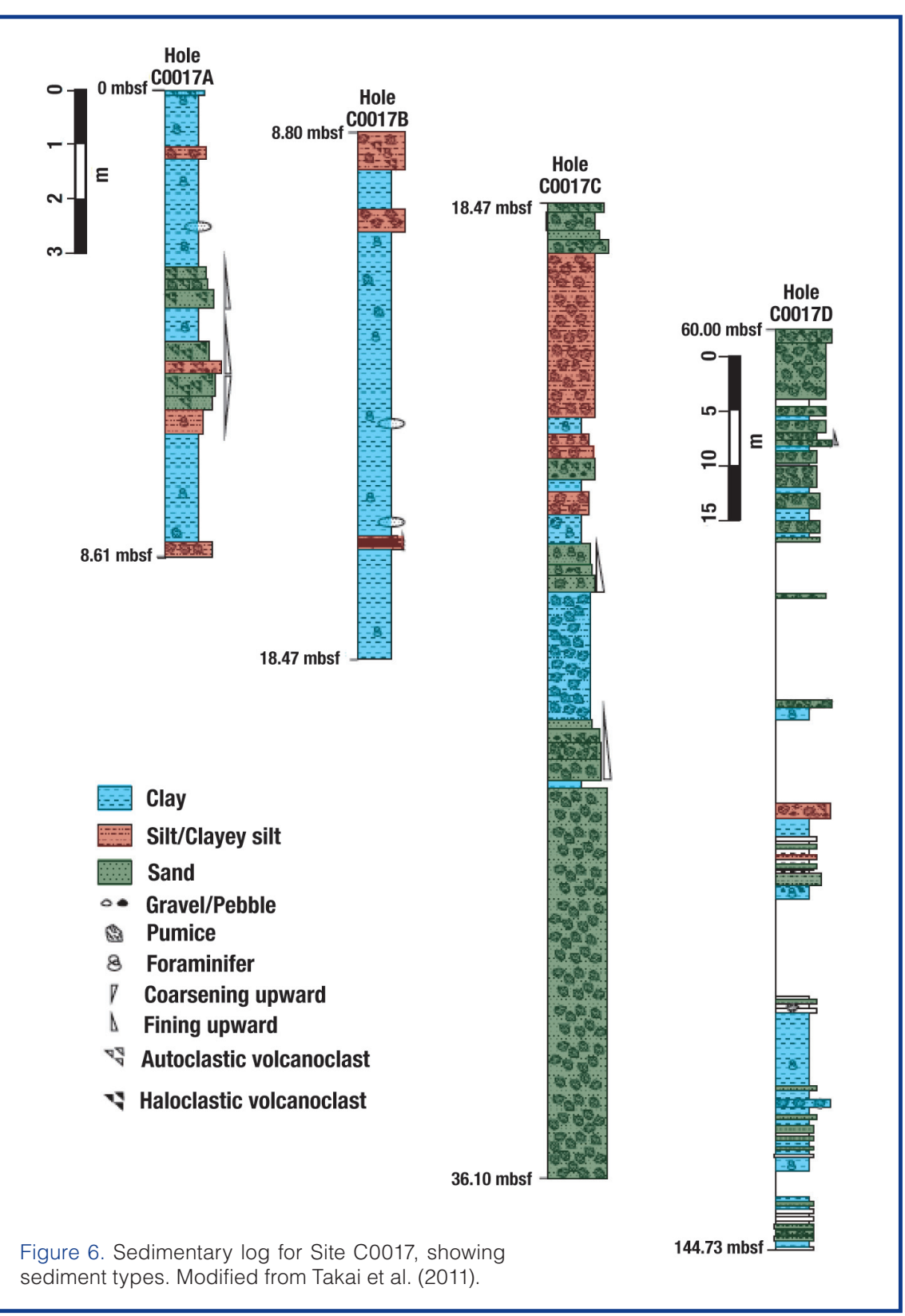

These results, taken together, provided a more detailed look at the large-scale hydrogeology of the Iheya North Knoll hydrothermal system than previously observed at subseafloor hydrothermal systems elsewhere (Takai et al., 2011). The hydrological regime at Iheya North Knoll was characterized by large-scale hydrothermal alteration, deposition, and fluid migration within permeable rocks and sediments hosted by the Iheya North Knoll volcanic complex. Prior to Expedition 331, we knew little about the spatial and temporal scales and patterns of hydrothermal circulation in subseafloor hydrothermal systems, particularly those in subduction zone settings such as volcanic arcs and backarc spreading centers.

Much of the sediment and rock we cored at Sites C0013, C0014, and C0016 was intensely hydrothermally altered, and mineralized (Fig. 5). Exceptional among the disseminated and vein, stockwork-type sulfide we recovered was the massive sphalerite-rich ore we cored in Hole C0016B. This marked the first time this type of massive sulfide, which closely resembles the Kuroko black ore, has been recovered from the subseafloor environment of an active deep-sea hydrothermal system. We recovered only 2.1 meters of core from $45 \mathrm{~m}$ of penetration in this hole, which made reconstruction of the lithostratigraphy impossible, but the recovered core included a wide diversity of lithologies that were typically associated with volcanic-hosted massive sulfide (VHMS) mineralization. In addition to the sphalerite-rich black ore, recovered core included a boulder-sized, coarsely crystalline piece of anhydrite veined by sphalerite-pyrite, as well as pyrite-veined and pyrite-altered volcanic rock.

The shipboard microbiological analyses and experiments provided little evidence for the existence of a hot subvent biosphere beneath the Iheya North hydrothermal field, though direct microscopic cell count and cultivation from a colder, diffusely venting site and a site of lateral recharge provided evidence for subseafloor psychrophilic to mesophilic microbial communities. Prior to this expedition, it was hypothesized that subseafloor mixing between hydrothermal fluids and recharging seawater was sustained by a fine-scale network of narrow hydrothermal fluid flow paths within the subseafloor along the eastern flank of the hydrothermal system. The hydrothermal regimes we intersected by drilling, including the permeable reservoirs and flow paths, appeared to be larger 
in scale than we had envisioned. Most of the sediment and rock we cored at Sites C0013, C0014, and C0016 were exposed to much higher temperatures than the microbiologically habitable temperature range $\left(<122^{\circ} \mathrm{C}\right)$. However, smaller and more limited zones that were habitable by microbes were sampled, as well as a larger one at the hydrothermal recharge zone at Site C0017. Recharge zones were, of course, an essential part of all hydrothermal systems.

\section{Plans for Future Investigations}

A total of twenty-four holes were drilled during Expedition 331, of which twenty-one resulted in recovered cores. We drilled $708 \mathrm{~m}$ and recovered 312 meters of core from $560 \mathrm{~m}$ attempted, yielding an overall recovery of $56 \%$. This compares highly favorably with the only other attempt to drill a submarine felsic-hosted hydrothermal system during ODP Leg 193, which recorded an overall core recovery of $10.7 \%$ at the PACMANUS site in the
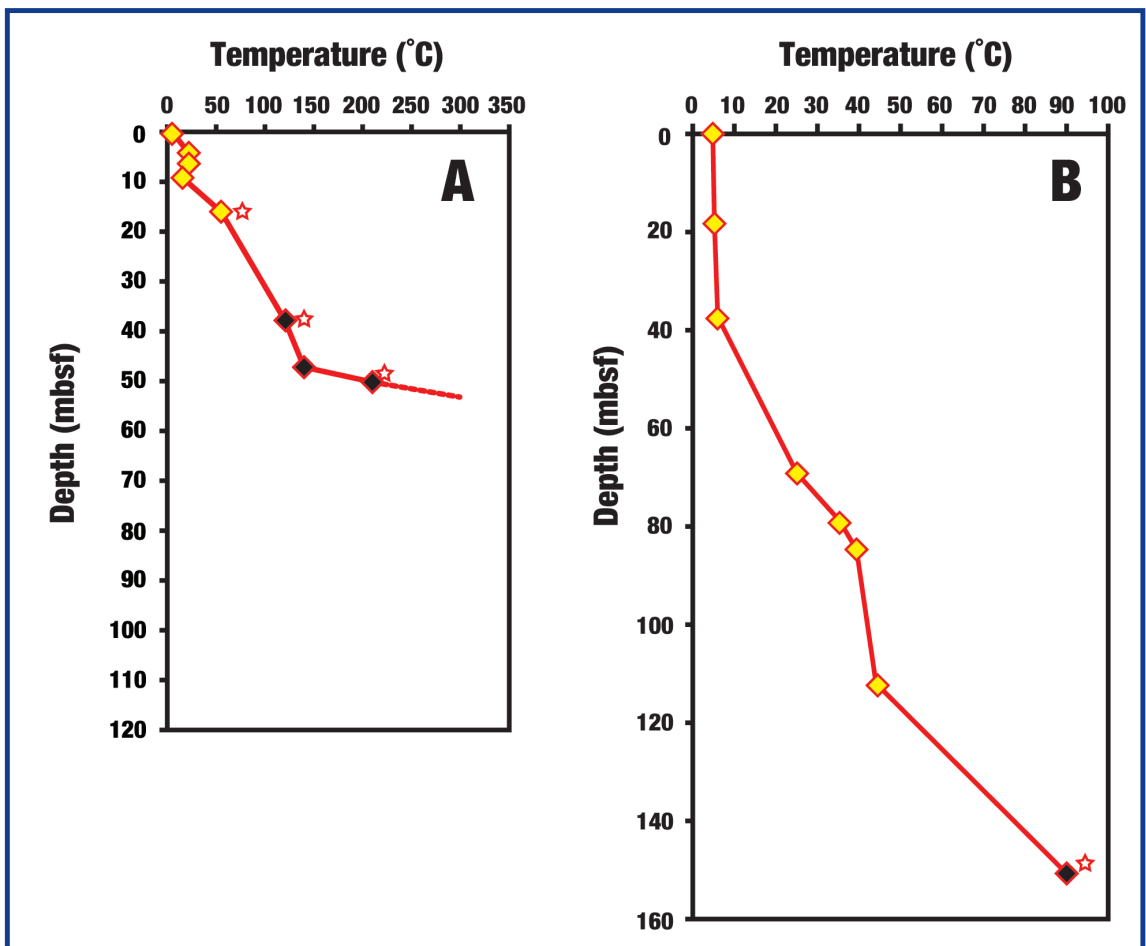

Figure 7. Depth profile of temperature in the subseafloor at Sites [A] C0014 and [B] C0017 as measured by the APCT3 shoe and thermoseal chemically impregnated temperature-sensitive strips. Yellow=APCT3, black=thermoseal strip. Stars=minimum values. Modified from Takai et al. (2011).

\section{Eastern Manus Basin, Papua New Guinea}

(Shipboard Scientific Party, 2002). The improved core recovery during Expedition 331 will provide excellent opportunities to assess the existence of a functionally active, metabolically diverse subvent biosphere and to clarify the architecture and function of subseafloor microbial ecosystems and the physical, geochemical, and hydrogeologic variations.

Holes C0013E and C0014G were cased with stainless steel pipe and capped with stainless steel corrosion caps with open outlets, and Hole C0016B was capped but not cased above a 3-m insertion pipe. Four post-drilling natural and artificial hydrothermal vents were created in Holes C0013E, C0014G, C0016A, and C0016B, in which hydrothermal fluid formerly trapped in the subseafloor ascended up the hole and exited into the ocean (Fig. 4). Temperature at all hydrothermal vent emissions was confirmed to be $>240^{\circ} \mathrm{C}$. These newly created hydrothermal vents will serve as windows into the subseafloor and will facilitate post-drilling, long-term studies of any associated microbial communities, fluid composition and flow, and in situ microbial and macrofaunal colonizations.

Interstitial water collected during Expedition 331 suggested that the subseafloor hydrothermal fluid regime of Iheya North field is chemically stratified with respect to chloride concentration. Pore water near the seafloor had the chloride concentration of seawater. It was underlain by a thin and possibly discontinuous vapor-rich layer at $\geq 5 \mathrm{mbsf}$ at Site C0013 and at 29-38 mbsf at Site C0014. Beneath the vapor-rich layer lays a chloride-enriched brine, at least to the maximum depth of the holes drilled at these two sites. Previous surveys of the Iheya North hydrothermal vents always found that the discharging fluids were low in chloride but rich in vapor (Kawagucci et al., 2011). It was a puzzle where the complementary brines resided. Several theoretical calculations predicted that the greater densities of brines caused them to sink to greater depths within subseafloor hydrothermal reservoirs (Fontaine and Wilcock, 2006). Expedition 331 provided tentative evidence of subseafloor stratification of hydrothermal fluids that had separated phases. The post-drilling investigation of the hydrothermal fluids discharging from the natural and artificial hydrothermal vents may provide further evidence of the chemically stratified subseafloor hydrothermal fluid regime of Iheya North field.

At Site C0016, drilling at the summit of the active hydrothermal mound failed to recover core, and drilling at the base of the mound yielded only 2.1 meters of core from $45 \mathrm{~m}$ of penetration, but the core included the first Kuroko-type, sphalerite-rich black ore ever recovered from the modern subseafloor. The other four sites yielded interbedded hemipelagic and strongly pumiceous volcaniclastic sediment, along with volcanogenic breccias that are variably hydrothermally altered and mineralized, in the zeolite to greenschist facies. Detailed studies of these lithologies, in the context of all that is known about the active hydrothermal system at Iheya North Knoll, will provide direct evidence of how VHMS mineral deposits in general, and the Kuroko ores in particular, are formed. 
Shipboard analyses did not confirm the presence of an active deep hot biosphere. Cell abundances were much lower than those found in previous Ocean Drilling Program/IODP sites on continental margins $\left(8.7 \times 10^{5}-2.4 \times 10^{7}\right.$ cells $\mathrm{mL}^{-1}$ sediment at Site C0013, $1.3 \times 10^{6}-4.1 \times 10^{8}$ cells $\mathrm{mL}^{-1}$ sediment at Site C0014 and $5.8 \times 10^{5}-2.4 \times 10^{7}$ cells $\mathrm{mL}^{-1}$ sediment at Site C0017; Takai et al., 2011), and attempts at culturing (hyper)thermophiles were generally unsuccessful. In fact, we found evidence for microbial activity in sediments within the upper 10-30 mbsf where temperatures were relatively low but little evidence in the deeper hydrothermally altered zones and hydrothermal fluid regime. Future shore-based, more detailed investigations may provide multiple lines of evidence for functionally active, metabolically diverse subseafloor microbial communities within the environments of the Iheya North hydrothermal system. In addition, the future investigations will seek to clarify the depth limits for the existence of microbial cells, metabolic activities, and living and fossil organic biomarkers in the subseafloor environment. These limits may represent a realistic boundary between the habitable and the uninhabitable zones in the subseafloor environments, namely a thermal barrier of the subseafloor biosphere.

\section{Acknowledgements}

We thank the captains, offshore installation managers, operation superintendents, and all the crew, expedition staff and technicians on Chikyu from Mantle Quest Japan and CDEX, JAMSTEC, who assisted us in drilling, sampling, installation, and measurements during Expedition 331. We also thank the proponents and all involved in preparation of IODP Proposal 601. Without their cooperation, this expedition could have never been fulfilled. The curatorial team provided us with their support during the expedition and upon the post-expedition sample requests.

\section{The IODP Expedition 331 Scientists}

K. Takai (Co-Chief Scientist), M.J. Mottl (Co-Chief Scientist), S.H. Nielsen (Expedition Project Manager), J.L. Birrien, S. Bowden, L. Brandt, A. Breuker, J.C. Corona, S. Eckert, H. Hartnett, S.P. Hollis, C.H. House, A. Ijiri, J. Ishibashi, Y. Masaki, S. McAllister, J. McManus, C. Moyer, M. Nishizawa, T. Noguchi, T. Nunoura, G. Southam, K. Yanagawa, S, Yang, and C. Yeats.

\section{References}

Deming, J.W., and Baross, J.A., 1993. Deep-sea smokers: Windows to a subsurface biosphere? Geochim. Cosmochim. Acta, 57(14):3219-3230. doi:10.1016/0016-7037(93)90535-5

Expedition 331 Scientists, 2010. Deep hot biosphere. IODP Prel. Rept., 331. doi:10.2204/iodp.pr.331.2010

Fontaine, F.J., and Wilcock, W.S.D., 2006. Dynamics and storage of brine in mid-ocean ridge hydrothermal systems. J. Geophys. Res., 111(B6):B060102. doi:10.1029/2005JB003866
Gamo, T., Ishibashi, J., Tsunogai, U., Okamura, K., and Chiba, H., 2006. Unique geochemistry of submarine hydrothermal fluids from arc-back-arc settings of the Western Pacific. In Christie, D.M., Fisher, C.R., Lee, S.-M., and Givens, S. (Eds.), Back-arc Spreading Systems: Geological, Biological, Chemical, and Physical interactions. Geophys. Monogr., 166:147-161. doi:10.1029/166GM08

Gamo, T., Sakai, H., Kim, E.-S., Shitashima, K., and Ishibashi, J., 1991. High alkalinity due to sulfate reduction in the CLAM hydrothermal field, Okinawa Trough. Earth Planet. Sci. Lett., 107(2):328-338. doi:10.1016/0012-821X(91)90080-2

Halbach, P., Nakamura, K., Wahsner, M., Lange, J., Sakai, H., Käselitz, L., Hansen, R.-D., et al., 1989. Probable modern analogue of Kuroko-type massive sulfide deposits in the Okinawa Trough back-arc basin. Nature, 338(6215):496499. doi:10.1038/338496a 0

Huber, J.A., and Holden, J.F., 2008. Modeling the impact of diffuse vent microorganisms along mid-ocean ridges and flanks. In Lowell, R.P., Seewald, J.S., Metaxas, A., and Perfit, M.R. (Eds.), Magma to Microbe: Modeling Hydrothermal Processes at Oceanic Spreading Centers. Geophys. Monogr., 178:215231. doi:10.1029/178GM11

Inagaki, F., Kuypers, M.M.M., Tsunogai, U., Ishibashi, J.-I., Nakamura, K.-I., Treude, T., Ohkubo, S., et al., 2006. Microbial community in a sediment-hosted $\mathrm{CO}_{2}$ lake of the southern Okinawa Trough hydrothermal system. Proc. Natl. Acad. Sci. U.S.A., 103(38):14164-14169. doi:10.1073/ pnas.0606083103

Kawagucci, S., Chiba, H., Ishibash, J., Yamanaka, T., Toki, T., Muramatsu, Y., Ueno, Y., et al., 2011. Hydrothermal fluid geochemistry at the Iheya North field in the mid-Okinawa Trough: Implication for origin of methane in subseafloor fluid circulation systems. Geochemical. J., 45(2):109-124.

Konno, U., Tsunogai, U., Nakagawa, F., Nakaseama, M., Ishibashi, J., Nunoura, T., and Nakamura, K., 2006. Liquid $\mathrm{CO}_{2}$ venting on the seafloor: Yonaguni Knoll IV hydrothermal system, Okinawa Trough. Geophys. Res. Lett., 33(16):L16607. doi:10.1029/2006GL026115

Lee, C.-S., Shor, G.G., Jr., Bibee, L.D., Lu, R.S., and Hilde, T.W.C., 1980. Okinawa Trough: Origin of a back-arc basin. Mar. Geol., 35(1-3):219-241. doi:10.1016/0025-3227(80)90032-8

Letouzey, J., and Kimura, M., 1986. The Okinawa Trough: Genesis of a backarc basin developing along a continental margin. Tectonophysics, 125(1-3):209-230. doi:10.1016/0040-1951 (86) $90015-6$

Nakagawa, S., Takai, K., Inagaki, F., Chiba, H., Ishibashi, J., Kataoka, S., Hirayama, H., Nunoura, T., Horikoshi, K., and Sako, Y., 2005. Variability in microbial community and venting chemistry in a sediment-hosted backarc hydrothermal system: Impacts of subseafloor phase-separation. FEMS Microbiol. Ecol., 54(1):141-155. doi:10.1016/j.femsec.2005.03.007

Narita, H., Harada, K., and Tsunogai, S., 1990. Lateral transport of sediment particles in the Okinawa Trough determined by natural radionuclides. Geochem. J., 24:207-216. doi:10.2343/ geochemj.24.207

Nunoura, T., and Takai, K., 2009. Comparison of microbial communities associated with phase-separation-induced hydrother- 
mal fluids at the Yonaguni Knoll IV hydrothermal field, the Southern Okinawa Trough. FEMS Microbiol. Ecol., 67:351370. doi:10.1111/j.1574-6941.2008.00636.x

Nunoura, T., Oida, H., Nakaseama, M., Kosaka, A., Ohkubo, S.B., Kikuchi, T., Kazama, H., et al., 2010. Archaeal diversity and distribution along thermal and geochemical gradients in hydrothermal sediments at the Yonaguni Knoll IV hydrothermal field in the southern Okinawa Trough. Appl. Environ. Microbiol., 76(4):1198-1211. doi:10.1128/ AEM.00924-09

Sakai, H., Gamo, T., Kim, E.-S., Shitashima, K., Yanagisawa, F., Tsutsumi, M., Ishibashi, J., et al., 1990. Unique chemistry of the hydrothermal solution in the mid-Okinawa Trough backarc basin. Geophys. Res. Lett., 17(12):2133-2136. doi:10.1029/GL017i012p02133

Shipboard Scientific Party, 2002. Leg 193 summary. In Binns, R.A., Barriga, F.J.A.S., Miller, D.J., et al., Proc. ODP, Init. Repts., 193: College Station, TX (Ocean Drilling Program). doi:10.2973/odp.proc.ir.193.101.2002

Suzuki, R., Ishibashi, J., Nakaseama, M., Konno, U., Tsunogai, U., Gena, K., and Chiba, H., 2008. Diverse range of mineralization induced by phase separation of hydrothermal fluid: Case study of the Yonaguni Knoll IV hydrothermal field in the Okinawa Trough back-arc basin. Res. Geol., 58(3):267288. doi:10.1111/j.1751-3928.2008.00061.x

Takai, K., and Nakamura, K., 2010. Compositional, physiological and metabolic variability in microbial communities associated with geochemically diverse, deep-sea hydrothermal vent fluids. In Barton, L., Mendl, M., and Loy, A. (Eds.), Geomicrobiology: Molecular and Environmental Perspective: New York (Springer), 251-283. doi:10.1007/978-90481-9204-5_12

Takai, K., Komatsu, T., Inagaki, F., and Horikoshi, K., 2001. Distribution of archaea in a black smoker chimney structure. Appl. Environ. Microbiol., 67(8):3618-3629. doi:10.1128/AEM.67.8.3618-3629.2001

Takai, K., Mottl, M.J., Nielsen, S.H., and the Expedition 331 Scientists, 2011. Proc. IODP, 331: Washington, DC (Integrated Ocean Drilling Program Management International, Inc.). doi:10.2204/iodp.proc.331.2011

Takai, K., Nakagawa, S., Reysenbach, A.L., and Hoek, J., 2006. Microbial ecology of mid-ocean ridges and backarc basins. In Christie, D.M., Fisher, C.R., Lee, S.M., and Givens, S. (Eds.), Back-Arc Spreading Systems: Geological, Biological, Chemical and Physical Interactions. Geophys. Monogr., 166:185-213. doi:10.1029/144GM23

Takai, K., Nunoura, T., Horikoshi, K., Shibuya, T., Nakamura, K., Suzuki, Y., Stott, M., et al., 2009. Variability in microbial communities in black smoker chimneys at the NW caldera vent field, Brothers Volcano, Kermadec arc. Geomicrobiol. J., 26(8):552-569. doi:10.1080/01490450903304949

Takai, K., Nunoura, T., Ishibashi, J., Lupton, J., Suzuki, R., Hamasaki, H., Ueno, Y., et al., 2008. Variability in the microbial communities and hydrothermal fluid chemistry at the newly discovered Mariner hydrothermal field, southern Lau Basin. J. Geophys. Res., 113:G02031. doi:10.1029/2007JG000636

Ueno, H., Hamasaki, H., Murakawa, Y., Kitazono, S., and Takeda, T.,
2003. Ore and gangue minerals of sulfide chimneys from the North Knoll, Iheya Ridge, Okinawa Trough, Japan. JAMSTEC J. Deep Sea Res., 22:49-62, http://docsrv.godac. jp/MSV2_DATA/23/22_06.pdf.

You, C.-F., Butterfield, D.A., Spivack, A.J., Gieskes, J.M., Gamo, T., and Campbell, A.J., 1994. Boron and halide systematics in submarine hydrothermal systems: Effects of phase separation and sedimentary contributions. Earth Planet. Sci. Lett., 123(1-3):227-238. doi:10.1016/0012-821X(94)90270-4

\section{Authors}

Ken Takai, Subsurface Geobiology Advanced Research (SUGAR) Project, Japan Agency for Marine-Earth Science \& Technology (JAMSTEC), 2-15 Natsushima-cho, Yokosuka 237-0061, Japan, e-mail: kent@jamstec.go.jp.

Michael J. Mottl, Department of Oceanography, School of Ocean and Earth Science and Technology (SOEST), University of Hawaii at Manoa, 1000 Pope Road, Honolulu, HI 96822, e-mail: mmottl@soest.hawaii.edu.

Simon H.H. Nielsen, Center for Deep Earth Exploration (CDEX), Japan Agency for Marine-Earth Science \& Technology (JAMSTEC), 3173-25 Showa-machi Kanazawa-ku, Yokohama 236-0001, Japan, e-mail: micropora@gmail.com.

\section{and the IODP Expedition 331 Scientists}

\section{Related Web Link}

http://www.jamstec.go.jp/chikyu/eng/Expedition/okinawa/exp331.html 